Hesselink, I. John ${ }^{1}$

Western Theological Seminary, Holland, Michigan

\title{
The distinctive nature of Calvin's Institutes and certain motifs in his theology
}

\begin{abstract}
Calvin's life, work, and theological writings are all of a piece. One cannot fully appreciate the Institutes if one is not aware of Calvin's own personal piety and consciousness of the presence of the Holy Spirit in his life. The Institutes was not even originally written as a dogmatic or systematic theology, but as an aid to the understanding of the Bible. Calvin's original intention was to write a handbook which would serve as an introduction to the reading of the Bible, not for theologians but for laity.
\end{abstract}

\section{INTRODUCTION}

Calvin, more than any other reformer, has been so mythologized in caricature and falsehood that few people know the real man. ${ }^{2}$ This is true even of many people of Reformed background. To a lesser extent the same thing is true of his theology, which is often depicted as cold and heartless with little or nothing about the love or grace of God. ${ }^{3}$ One of the myths that perseveres even in relatively sophisticated theological circles is that Calvin was not an original theologian or thinker but a man with a genius of systematizing the insights of the first generation of reformers. Harnack, at the end of his great History of Dogma merely dismisses Calvin in about one page as an epigone of the Reformation. (Epigone means an inferior imitator of a writer or an artist.) This is repeated by Friedrich Loofs in his Dogmengeschichte written in 1906. Those in the Reformed tradition, or at least knowledgeable Calvin scholars, have never taken such charges seriously; and finally, in this quincentennial celebration of Calvin's birth the reformer is being evaluated fairly. ${ }^{4}$

Calvin was indeed indebted to his predecessors and colleagues, not to mention the church fathers, especially Augustine. He learned much from Luther and Bucer, his one-time colleague at Strasbourg, as well as Melanchthon, whom he admired greatly. It is very interesting that from Zwingli himself, the first Reformed reformer, Calvin by his own testimony learned the least of all.

1 Albertus C. Van Raalte, Professor of Systematic Theology, Western Theological Seminary, Holland, Michigan. This lecture was presented in the week of 11-15 July 2011 at Stellenbosch as visiting professor in the Discipline Group of Systematic Theology and Ecclesiology, Faculty of Theology, Stellenbosch University. .

2 Karin Maag disposes of many of their myths in her essay "Hero or Villain? Interpretations of John Calvin and His Legacy," in Calvin Theological Journal 41/2 (Nov. 2006).

3 The popular historian Will Durant is typical of a generation of writers who have never read Calvin and simply repeat old slanders and caricatures. Speaking of Calvin he writes, "We shall always find it hard to love the man who darkened the human soul with the most absurd and blasphemous conception of God in the long and honored history of nonsense," The Reformation in the series "The Story of Civilization," Vol. VI (New York: Simon and Schuster, 1957), 490.

4 Of the many biographies of Calvin that were published in 2009, two merit special attention: John Calvin. A Pilgrim's Life by Herman J. Selderhuis (Downer's Grove, IL: IVP Academic, 2009); and the magisterial study by Bruce Gordon, Calvin (New Haven, Conn.: Yale U. Press, 2009). 
In fact, he had a surprisingly low regard for the work of the Zurich reformer, partially because he was influenced by Luther in this regard. ${ }^{5}$

\section{THE NATURE OF THE INSTITUTES}

Yet, despite the undeniable debt he owed to all these men, he was no mere collator. As a theologian he surpassed them all. To be sure, he was more constructive than imaginative, and more logical than intuitive, but his was still a powerful and original mind in the way in which he reworks the fundamental doctrines of the Reformation. In his peculiar emphases and distinctive development of certain themes he reveals his genius, not just systematic, but also creative genius. As the French Calvin scholar, Francois Wendel, has observed, the history of philosophical and theological doctrines demonstrates that what appears to have been the most novel and even revolutionary ideas owe their originality much more to the new arrangement of conceptions known long ago than to the creative power of those who are regarded as their inventor. ${ }^{6}$ Calvin is not an exception to that general rule.

Moreover, for all Calvin learned from great scholars, he was first and foremost a student of the Scriptures. It is to his assiduous reading of the Bible and especially the Psalms, the prophets, and St. Paul that we must look for the source of many subtle shades of meaning in his theology and, more generally, the light upon his religious mentality. In fact, "Calvin's Institutes can be regarded as a work of biblical theology which both affirms the centrality of Scripture, while at the same time offers a unifying and coherent interpretation of Scripture. ${ }^{77}$ This is only one of the aspects of the Institutes that runs counter to the usual understanding of this classic.

A careful reading of the Institutes will produce other surprises. In the first place, it was not even originally written as a dogmatic or systematic theology, but as an aid to the understanding of the Bible. Calvin's original intention was to write a handbook which would serve as an introduction to the reading of the Bible, not for theologians but for laity. In succeeding editions his purpose was modified somewhat, but it never became a philosophical or speculative system as such.

In the second place, it has often been overlooked that whatever other purpose Calvin might have had in mind-and he had several-a fundamental concern was "the upbuilding of godliness and piety." The title of the first edition of the Institutes (1536), reads Institutes of the Christian Religion. Embracing almost the whole sum of piety and whatever is necessary to know of the doctrine of salvation. ${ }^{8}$ From 1539 on he used the simpler title, the Institutes of the Christian Religion. But his zeal for piety, or godliness, ${ }^{9}$ so characteristic of his own life, continued to be one of the goals of his work. In the "Prefatory Address to King Francis I of France" he writes, "My purpose [in the Institutes] was solely to transmit certain rudiments by which those who are touched with any zeal for religion might be shaped to true godliness (formarentur ad veram pietatem). ${ }^{10}$ Not only does this word recur with great frequency in the Institutes, pietas is, according to Calvin, the prerequisite for the true knowledge of God and the source of all true religion.

5 See Gordon, Calvin, 2007.

6 Calvin, Origins and Development of His Religious Thought (New York: Harper \& Row, 1963), 11, 357360 .

7 Alister Mc Grath, "The Shaping of Reality: Calvin and the Formation of a Theological Vision," lecture given at a Calvin Conference at the University of Toronto, June 19, 2009. Unpublished manuscript, p. 16.

8 From the English translation by Ford Lewis Battles (Grand Rapids: Eerdmans and the H. Meter Center for Calvin Studies, 1986), title page. A Korean translation of the first edition of the Institutes has recently been completed by Byung Ho Moon.

9 Pietas (Latin) or pieté (French) is translated sometimes as 'piety,' other times as 'godliness.'

$10 \mathrm{Mc}$ Neill-Battles edition of the Institutes, 9. 
It is difficult to define piety or godliness as Calvin uses this term, for it is such a comprehensive concept for him. Sometimes it is equated with "true religion" (Inst. I.2.1). He defines it briefly as "that reverence joined with the love of God which the knowledge of his benefits induces (Inst. I.2.1). Calvin can even go so far as to say that "Godliness (pietas) is the beginning, middle, and end of Christian living, and where it is complete, there is nothing lacking." 11

In any case, it is quite different from the seventeenth century pietism of Spener and Francke and the vagaries of what today often passes for piety. It is also different from the current emphasis on spirituality which is often very individualistic and inner directed. For Calvin, on the contrary, piety includes not only the love and worship of God but also the service of God and is lived out in the context of the church. ${ }^{12}$

It is not too much to say that the concept of piety is the clue to understanding Calvin the man and the nature of the Institutes. S. Y. Lee is quite right in affirming, "It could be said that pietas was Calvin's entire theological direction and goal rather than merely one theme in his theology." 13 This is what makes the Institutes of the Christian Religion unique and an enduring classic which is being read more widely today than ever before.

Calvin had other goals in writing the Institutes-i.e., brevity and simplicity, ${ }^{14}$ and only that which is useful and profitable. ${ }^{15}$ But it is this goal-unusual for a dogmatic or systematic theology - to produce a work that would be useful and edifying-that makes it special. "The essential character" of Calvin's theology, writes Brian Armstrong, "is that his theology is simply for the purpose of providing for the nurture of the saints . . . . his theology is intended for exclusively spiritual ends, for spiritual edification." 16

Calvin expresses all this in some oft-quoted lines:

Let us remember here, as in all religious doctrine, that we ought to hold to one rule of modesty and sobriety: not to speak, or guess, or even to seek to know, concerning obscure matters anything except what has been imparted to us by God's Word. Furthermore in the reading of Scripture we ought ceaselessly to endeavour to seek out and meditate on those things which make for edification. Let us not indulge in curiosity or in the investigation of unprofitable things (Inst. I.14.4).

In short, "The theologian's task is not to divert the ears with chatter, but to strengthen consciences by teaching things true, sure and profitable (vera, certa, utilia)" (Ibid). Or, to use more contemporary language, in this classic work, we also have a pastoral theology, for as a French scholar points out, in the Institutes we have not only "a book of profound and solid

11 Comm. 1 Timothy 4:8.

12 See Institutes IV.1.6, 12. Older Calvin studies often ignored the significance of piety in Calvin's life and theology. That is no longer the case. Cf. The Spirituality of John Calvin by the Roman Catholic theologian Lucien Joseph Richard, O.M.I. (Atlanta: John Knox Press, 1974); The Piety of John Calvin by Ford Lewis Battles (Grand Rapids: Baker, 1978); John Calvin. Writings on Pastoral Piety, edited with translations by Elsie Anne Mc Kee (Mahwah, NJ: Paulist Press, 2001); and the shorter theological analyses by I. John Hesselink in Calvin's First Catechism. A Commentary (Louisville: Westminster John Knox, 1997), 45-47; and "Calvin on Piety" by Joel Beeke in The Cambridge Companion to John Calvin, edited by Donald Mc Kim (Cambridge, England: Cambridge U. Press, 2004).

13 "Calvin's Understanding of Pietas," unpublished seminar paper presented at the International Calvin Congress in Edinburgh, September, 1994.

14 Cf. the 1998 Pretoria University doctoral dissertation of Myung Jun Ahn, Brevitas et Facilitas. A Study of a Vital Aspect in the Theological Hermeneutics of John Calvin.

15 "Let those who dearly love soberness and who will be content with the measure of faith receive in brief form what it is useful to know," Inst. I.14.1.

16 "Duplex Cognitio Dei, Or? The Problem and Relation of Structure, Form, and Purpose in Calvin's Theology," in Probing the Reformed Tradition. Historical Studies in Honour of Edward A. Dowey, Jr., edited by Elsie Anne Mc Kee and Brian G. Armstrong (Louisville: Westminster John Knox, 1989), 138-9. 
learning" but one which is concerned "with the heart and the care of souls. . . The Institutes is not only the book of a theologian; it is the book of a man who even before he became a pastor was haunted by a concern for souls." 17

The other side of the coin is that Calvin abhorred abstract speculative reasoning. If a doctrine was not useful-another key word of his theology-he was not much interested in it. One of the dirty words in the Institutes is "frigid and empty speculation." He cautions his readers again and again that this snare is to be avoided above all (Inst. I.4.1; I.14.3, 4). "Here again [in the creation] we are called to a knowledge of God: not that knowledge which, content with empty speculation, merely flits on the brain, but that which will be sound and fruitful (solida et fructuosa) ... and if it takes root in the heart" (Inst. I.5.9).

Third, a critical reader of the Institutes will soon discover that for rigorous, logical reasoning in a neatly arranged system, the Institutes is inferior to works of Aquinas and Schleiermacher, or to Barth and Tillich, for that matter. Calvin's Institutes is undoubtedly a masterpiece of orderly reflection, but it is no rigid system built upon some arbitrary set of principles. As a biblical scholar, Calvin found it impossible to keep within a predetermined structure. Didactic and polemic interests also frequently forced him to deviate from a more systematic approach. Actually, it is possible to fault Calvin in several places for not developing certain motions or doctrines more systematically. This was perceived, although in a one-sided fashion, by Herman Bauke in a work that he wrote in 1922, Die Probleme der Theologie Calvins, in which he maintains that Calvin's theology is a host of unresolved paradoxes. This is going too far, but it does point at a truth that has been overlooked. A few illustrations should suffice. Note how Calvin begins in Book I. This is no prolegomena as we usually think of one, with a long discussion about various ways that God is known and proofs of the existence of God, or even of God's attributes, nor a lengthy discussion of revelation. It begins experientially, even existentially, with a very practical question, "How can we know God?" The answer is that central to everything is the knowledge not only of God but also of ourselves, and that these two, knowledge of self and knowledge of God, are so intertwined that one cannot know himself without knowing God and vice-versa-a remarkably contemporary approach (Inst. I.1.1).

Second, take a look at Book II. Here you find a discussion of the law. It would fit more logically in the third book which speaks of sanctification and the work of the Holy Spirit. The third use of the law for Calvin, the law as a guide for Christians, was the principle use. But he discusses it in the second book before he comes to his Christology as such. Why? Because he develops the law in terms of Heilsgeschichte, the history of salvation, and therefore it falls in his Christology rather than his doctrine of the Holy Spirit.

Then take a look at Book III. How does he begin his development of the appropriation of the work of Christ? The whole thing is developed under the idea of the Holy Spirit, but he does not begin with regeneration as usually understood, or justification but with sanctification. Later, after several chapters, he deals with justification-obviously a strange order from the logical standpoint. In fact, you will find no ordo salutis (order or plan of salvation) in Calvin's Institutes.

Take a look at Book IV. What do theologies usually end with, at least traditionally? - with eschatology. At the end of Book Four you find no eschatology but a treatment of civil government. This, I say, is a strange dogmatics. As John T. Mc Neill rightly observes, "One who takes up Calvin's masterpiece with a preconception that its author's mind is a kind of efficient factory turning out and assembling parts of a neatly jointed structure of dogmatic logic will quickly find this assumption challenged and shattered."18

17 Calvin Directeur l'Ames (Strasbourg: Oberlin, 1947), 14. Translation mine.

18 Introduction to Library of Christian Classics edition of the Institutes edited by Mc Neill and translated by Ford Lewis Battles, li. 


\section{SOME KEY MOTIFS IN CALVIN'S THEOLOGY}

However, even if we grant that Calvin was original and not just a Lutheran epigone, a man of warmth and experience and not an inflexible abstract logician, we still have not come to what is distinctive about the content of Calvin's theology. This has all been necessary by way of introduction, although I have suggested certain aspects such as his biblical grounding and his zeal for piety. Until rather recently it was always assumed that Calvin's system could be boiled down to some central idea, a single dogma which in turn would be the key that would unlock the mysteries of his whole theology. But for some time now Calvin scholars have pointed out the fallacy of trying to limit the distinctiveness of Calvin's theology to some key principle or central doctrine. The human mind, it is true, craves a neat system. However, "if we want to speak of a 'system' of Calvin, we must do so with certain reservations, owing to the plurality of themes that impose themselves simultaneously upon its author's thinking." 19 And hence to try to capture Calvin's "system" with such notions as the sovereignty of God, predestination, the glory of God, the covenant, etc., is misleading. In any case, all these single notions, whether predestination or the sovereignty of God or the covenant, fail to do justice to the scope and the breadth of Calvin's theology.

Here the German Calvin scholar, Wilhelm Niesel, has made a significant contribution. For he agrees that there is no one special doctrine by which Calvin's theology can be described. Yet he feels, and rightly so, that we must grasp the kernel or peculiar nature of Calvin's theology or we will never really understand his thought. Niesel finds this golden thread which runs through all of Calvin's theology in this: that Calvin does not simply attempt to expound the meaning of the Scriptures in a general and abstract way, but rather that he seeks to relate his readers to the key and end, the scopus of the Scriptures, namely, Jesus Christ. "The aim of all of our attention to the Bible should be the recognition of Jesus Christ. ... In every aspect of doctrine Calvin is concerned only about one thing: namely, the God revealed in the flesh."20

Niesel here, as elsewhere in his study of Calvin's theology, reflects too much the influence of his mentor (and mine) Karl Barth. Because Barth has attempted to be radically and thoroughly Christ centric in his theology, Niesel as a good Barthian is eager to make Calvin agree with Barth at this point. (I once discussed Niesel's interpretation of Calvin with Barth, and Barth himself agreed, with his usual good humour, that Niesel in his theology of Calvin sometimes reads Calvin with Barthian glasses.)

To be sure, Calvin, like all evangelical theologians, is Christ centric; but it is possible to be so Christ centric that one is no longer biblical. Even so, Niesel's point is well taken. Calvin repeatedly notes that Christ is the centre, the soul, the life, the end, or goal, of the Scriptures.

In his commentary on Romans 10:4-"Christ is the end of the law"-Calvin agrees with Erasmus that 'end' (Telos in Greek) could also be translated as 'completion' or 'perfection' and comments, "Every doctrine of the law [i.e., Scripture], every command, every promise, always points to Christ. We are therefore to apply (dirigendae sunt) all its parts to him." 21 Therefore, if we try to read the Scriptures without taking concern of Christ and noting that it points to him, we cannot properly understand them. And so Calvin was indeed Christ centric. But this is not the distinctive thing about Calvin's interpretation of Scripture. Hence I feel that this is an inadequate clue for understanding the peculiar nature or distinctive traits of Calvin's theology. Luther, before Calvin, had precisely the same emphasis.

What is interesting is that whereas older, more traditional orthodox Calvinists found the clue

19 Wendel, Calvin, 357.

20 The Theology of Calvin (Philadelphia: Westminster, 1956), 246.

21 Comm. Rom. 10:4. C f. Institutes II.7.2. 
to Calvin's theology in the doctrine of God (particularly his sovereignty), ${ }^{22}$ as over against the neo-orthodox emphasis upon Christ, long ago an orthodox Calvinist by the name of B. B. Warfield proposed that Calvin was above all "the theologian of the Holy Spirit." He adds, "The doctrine of the Holy Spirit is a gift of Calvin to the church." 23 This has been affirmed subsequently by a number of Calvin scholars. For example, Werner Krusche, in his outstanding book on the work of the Holy Spirit in Calvin's theology agrees and goes on to say that if you have to pick one person of the Trinity, it is the third person who is most characteristic of Calvin's approach to theology. ${ }^{24}$ The Roman Catholic Calvin scholar, Alexandre Ganoczy agrees. "Pneumatology," he says, "is present everywhere in Calvin's thought." 25

Calvin's most distinctive contribution to the doctrine of the Holy Spirit is the way in which he establishes the authority of Scripture. The Scriptures contain within themselves "very useful aids" that are evidence of their divine origin, but these are only of secondary value (Inst. I.8.1). For

the certainty that our consciences require in regard to the authority of Scripture is only found in the "secret testimony of the Spirit (arcane testimonio Spiritus)." This alone will persuade us "beyond doubt that God is its author" Inst. I.7.4). Argumentation and rational proofs will be of little or of no avail in trying to establish this kind of certainty. For The testimony of the Spirit is more excellent than all reason. For as God alone is a fit witness of himself in his Word, so also the Word will not find acceptance in men's hearts before it is sealed by the inward testimony (interiore testimonio) of the Spirit (Inst. I.7.4).

Calvin continues this line of reasoning in the next section of chapter 7, where he argues that Scripture is autopistos, that is, it bears its own authentication. "Those whom the Holy Spirit has inwardly taught truly rest upon Scripture, and that Scripture indeed is self-authenticated." Again, this kind of certainty only comes from "the testimony of the Spirit" and "seriously affects us only as it is sealed upon our hearts through the Spirit." Not only that, the Spirit convicts us that "Scripture is from God" and "has flowed from the very mouth of God by the ministry of men" (Inst. I.7.5).

Time limitations do not permit a discussion of all of the key motifs in Calvin's theology. In my essay on Calvin's theology in The Cambridge Companion to Calvin's Theology, ${ }^{26}$ in addition to stressing the centrality of the Word and the Spirit and the incarnate Word, I enumerated a number of other distinctive contributions of Calvin to theology, viz.:

1. "An Appreciation for the created order"

2. "God's providential care for the universe and its inhabitants"

3. "The polemic against idolatry"

4. "One covenant of grace"

5. "The significance of the humanity of Christ"

6. "The threefold office of Christ (triplex munus Christi)"

7. "The knowledge of faith"

22 Calvin speaks more often of the majesty of God than the sovereignty of God.

23 Calvin and Augustine (Philadelphia: Presbyterian and Reformed Publishing Co., 1956), 484-5.

24 Das Wirken des Heiligen Geistes nach Calvin (Göttingen: Vandenhoeck and Ruprecht, 1957), 12, 339.

25 "Calvin," in Pierre Chaunu, ed., The Reformation (Gloucester, England: Alan Sutton, 1989), 135. It is not too much to say that "for Calvin, every apprehension of God depends on the activity of the Holy Spirit. ... At the edges and limits of Calvin's thought, the Spirit takes over," John Dillenberger, John Calvin (Garden City, NY: Anchor Books, 1971), 18. I have discussed Calvin's doctrine of the Holy Spirit in an appendix: "Calvin, Theologian of the Holy Spirit" in my book Calvin's First Catechism. A Commentary (Louisville: Westminster John Knox, 1997), 177-187; and also in an essay "Pneumatology" in The Calvin Handbook, edited by Herman J. Selderhuis (Grand Rapids: Eerdmans, 2009), 299-312.

26 Edited by Donald K. Mc Kim (Cambridge, UK: Cambridge University Press, 2004), 74-92. 
9. "The unity and catholicity of the church"

10. "Civil government as an instrument of God"

I have discussed many of these themes in various journals and books and cannot elaborate on them here. However, I have become aware of my failure to emphasize a major motif in my essay, viz., our faith union with Jesus Christ and all that this entails. ${ }^{27}$ Many years ago Francois Wendel mentioned the significance of this theme in the conclusion to his book on Calvin. "The imprint of Calvin's personality," Wendel says, "can best be seen in the emphasis he put on this or that doctrine, and in the practical consequences that he was concerned to draw from his notion of union with Christ"28 (emphasis mine).

In recent years this has become a major motif in many Calvin studies, although Calvin's single reference to our "mystical union" 29 with Christ has always attracted some attention. Calvin describes this as a "joining together of head and members, that indwelling of Christ in our hearts," which, Calvin adds, "are accorded by us the highest degree of importance (in summe gradu statuitur)" (ibid).Calvin scholars are quick to point out that this "mystical union" does not imply "any absorption into Christ." 30 As Calvin himself points out earlier in this chapter (in his refutation of Osiander) "Christ's essence is not mingled with ours" (III.11.5). However, Calvin emphasizes again the importance of this notion of our incorporation in the body of Christ through the Holy Spirit. This is a present reality but also has eschatological implications. Calvin is convinced he is only echoing the Apostle Paul in Romans 8:10 when he (Calvin) states that "Christ is not outside us but dwells within us. Not only does he cleave to us by an indivisible bond of fellowship (individuo societas nexu) but with a wonderful communion, day by day, he grows more and more into one body with us until he becomes completely one with us" (Inst. III.2.24).

The eschatological significance of our union with Christ (which is the same as being incorporated into Christ) is seen in Calvin's comments on 1 Corinthians 6:20-"Do you not know that your bodies are members of Christ?" "The spiritual union which we have with Christ," Calvin says, "is not a matter of the soul alone but the body also so that we are flesh of his flesh, etc. (Eph. 5:20). The hope of the resurrection would be faint if our union with him were not complete and total like that." 31

Our incorporation into Christ also has consequences for the doctrines of justification and sanctification. Calvin's view of justification is quite traditional, i.e., forensic. We are declared righteous by virtue of our faith in Christ and Christ's righteousness is imputed to us (Inst. III.11.23). However, Calvin moves beyond this traditional forensic view of justification-and the view that sanctification is simply a process of growing in holiness-with his emphasis on our incorporation into Christ. "You see that our righteousness is not in us but in Christ, but we possess it only because we are partakers (participles) in Christ" (Inst. III.11.23, emphasis mine). Our justification, then, is not simply an external declaration but a personal reality by virtue of our union with Christ. Here Calvin moves beyond Luther and later orthodox understandings of justification when he also says, "Thus him whom Christ receives into union with himself the

27 I do mention this motif briefly on page 81 in the context of the importance of the incarnate eternal Word.

Whereas "Luther lays more emphasis on Christ for us (pro nobis), Calvin on Christ in us (in nobis).

Therefore, another distinctive doctrine of Calvin is often held to be the notion of the mystical union with

Christ (Inst. III.11.10). . . ."

28 Calvin, 360. The original French version of this classic was published in 1950, the English translation

in 1963. Wilhelm Kolfhaus wrote a whole book on this subject in 1938, viz., Christusgemeinshaft bei

Johannes Calvin (Neukirchen: Buchhandlung \& Erziehungsvereins).

29 Unio mystica in Latin but union sacrée in the French (1530) version.

30 Wendel, Calvin, 235. Cf. Niesel, Theology of Calvin, 126.

31 Comm. 1 Corinthians 6:20. 
Lord is said to justify because he cannot receive him into grace nor join him to himself unless he turns him from a sinner into a righteous man... This is done through forgiveness of sins" (Inst. III.11.21).

Thus by "partaking in Christ, we principally receive a double grace." This duplex gratia results in our "being reconciled to God through Christ's blamelessness so that we may have in heaven instead of a Judge a gracious Father; and secondly that sanctified by his Spirit we may strive after blamelessness and purity of life" (Inst. III.11.1, Battles translation amended). Calvin expresses the same truth in his comment on Galatians 2:20:

Christ lives in us in two ways. The one consists in his governing us by his Spirit and directing

all our actions. The other is what he grants us by participating in his righteousness,

that since we can do nothing of ourselves, we are accepted by him [Christ] by God. The

first relates to regeneration [i.e., sanctification], the second to the free acceptance of

righteousness ${ }^{32}$ [i.e., justification].

In reference to this "double grace" in Calvin, Todd Billings argues "that one cannot simply label Calvin's doctrine . . . wholly forensic or simply reducible to a non-forensic account of 'union with Christ." It is forensic, Billings acknowledges, but "Calvin's theology of union with Christ is articulated with reference to participation, adoption, imputation, and the wondrous exchange. It is a multi-faceted doctrine, utilizing both legal and transformative images."33

This motif of union with Christ-or with God $^{34}$ - has other ramifications. Charles Partee in his recent book The Theology of John Calvin ${ }^{35}$ agrees with recent Calvin scholarship that there is no central dogma in Calvin's Institutes, but at the same time he is convinced that "the doctrine of union with Christ is close to the centre stage in Calvin's theology." ${ }^{36}$ As I have indicated earlier, this is not a new idea. Partee even points to John Nevin, one of the Mercersburg theologians, who in the 1840s submitted that union with Christ was a central motif in Calvin's theology. ${ }^{37}$ And in our time this notion has been widely recognized as one of Calvin's most important contributions to Christian theology. ${ }^{38}$ David Willis-Watkins states the case very nicely: "Calvin's Doctrine of Union with Christ is one of the most consistently influential features of Calvin's theology and ethics, if not the single most important teaching that animates the whole of his thought and his personal life." 39

\section{CONCLUSION}

Calvin's life, work, and theological writings are all of a piece. One cannot fully appreciate the Institutes if one is not aware of Calvin's own personal piety and consciousness of the presence

32 Comm. Galatians 2:20.

33 Calvin, Participation and the Gift. The Activity of Believers in Union with Christ (Oxford, England:

Oxford U. Press, 2007), 25. Cf. 191.

34 Billings shows that Calvin also speaks of "union with God," Participation and the Gift, 16-17. However, Billings usually speaks of our participation in Christ or God.

35 Louisville: Westminster John Knox, 2008.

36 The Theology of John Calvin, 274. Partee also speaks frequently of "union in Christ," Partee also points out the relevance of this motif for Calvin's doctrine of predestination (252) and the church (269).

37 The Theology of John Calvin, 41, n. 143.

38 Cf. Dennis E. Tamburelo, Union with Christ. John Calvin and the Mysticism of St. Bernard (Louisville: Westminster John Knox, 1994); Ronald S. Wallace, Calvin's Doctrine of the Christian Life (Edinburgh: Oliver and Boyd, 1959), 17-27; and I. John Hesselink, Calvin's First Catechism, 103f., 185f.

39 David Willis-Watkins, "The Unio Mystica and the Assurance of Faith according to Calvin," in Calvin Erbe und Auftrag: Festschrift für Wilhelm Heinrich Neuser Zum 65. Geburtstag (Kampen: Kok, 1991), ed. by Willem van't Spiker. 
of the Holy Spirit in his life. To get a full picture of Calvin's life and work, of course, one must also read Calvin's commentaries, sermons, and correspondence. ${ }^{40}$ However, whereas Calvin's theology is thoroughly Trinitarian, more than any other reformer the role of the Holy Spirit is prominent in his theology. A special manifestation of this is seen in his doctrine of our faith union with, or incorporation in, Christ, which is effected by the Holy Spirit. This gives a warmth and dynamic to the reformer's theology that speaks to our age 500 years after his birth.

40 One of the virtues of the recent biography of Calvin by Herman J. Selderhuis, John Calvin. A Pilgrim's Life (Downers Grove, IL, 2009), is that he relies heavily on Calvin's letters and is thus able to give a fresh portrait of the reformer. 